\title{
Offering HCV treatment to prisoners is an important opportunity: key principles based on policy and practice assessment in Europe
}

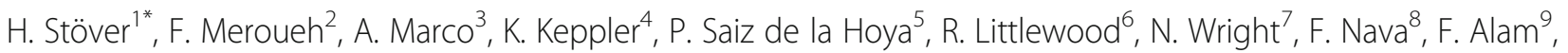
S. Walcher ${ }^{10}$ and L. Somaini ${ }^{11}$

\begin{abstract}
Background: Prisoners have a high prevalence of hepatitis $\mathrm{C}$ virus (HCV) infection but may find it difficult to access healthcare services. This may be related to risk behaviour including history of injecting drugs and marginalisation related to problem drug use/ opioid use disorder (OUD). Direct-acting antiviral products with superior efficacy and safety compared to interferon-based regimens offer HCV cure. Many citizens in Europe have been treated, although few received therapy in prisons.

Methods: Analysis of prisoner HCV treatment need and policy determinants of clinical practice was completed for 5 EU countries. Evidence was collected from national statistical sources and peer-reviewed publications to describe prison populations and HCV prevalence, to map national prison/ HCV health policy or guidance. A consensus of important principles for prisoner HCV care was developed.

Results: Data from published sources describing prisoner HCV prevalence is limited. Prisoner population requiring HCV treatment is not known; estimated numbers based on analysis of evidence: England and Wales, 9000, France, 8000, Spain, 6000, Italy, 6000, Germany, 6000. Treatment access: national law defines right to equivalent care in all countries implying access to HCV therapy in prison similar to community; useful prisoner HCV guidance facilitating treatment decisions present in: 4 of 5 national/ regional HCV policy documents, 4 of 5 national prison healthcare policies. Four of five had practical prison HCV clinical guidelines. Despite existence of policy, implementation of guidance, and so HCV treatment, is suboptimal in many locations.

Conclusions: Prison is an important location to detect, address and treat HCV infection in people who may be underserved for healthcare and find it difficult to navigate community treatment pathways. This is often related to problems with OUD and resulting social inequity. HCV management in prisons must be improved. Policy and clinical practice guidance must be set to promote treatment, and practical steps to make treatment easy should be followed including education to promote engagement, set-up of optimal screening and work up processes with modern tools to reduce time needed/ achieve efficiency; programs to make it easier to get specialists' input include remote working and nurse-led services.
\end{abstract}

Keywords: Hepatitis C virus, Treatment, Prisoners, Policy, Practice

\footnotetext{
* Correspondence: hstoever@fb4.fra-uas.de

${ }^{1}$ Institute of Addiction Research, Frankfurt University of Applied Sciences,

Frankfurt, Germany

Full list of author information is available at the end of the article
}

(c) The Author(s). 2019 Open Access This article is distributed under the terms of the Creative Commons Attribution 4.0 International License (http://creativecommons.org/licenses/by/4.0/), which permits unrestricted use, distribution, and reproduction in any medium, provided you give appropriate credit to the original author(s) and the source, provide a link to the Creative Commons license, and indicate if changes were made. The Creative Commons Public Domain Dedication waiver (http://creativecommons.org/publicdomain/zero/1.0/) applies to the data made available in this article, unless otherwise stated. 


\section{Background}

Chronic hepatitis $\mathrm{C}$ virus (HCV) infection is prevalent in people with a history of injecting drugs [1-3] - many of these people have a history of opioid use disorder (OUD) [4]. Individuals with OUD and a history of injecting drugs are often marginalized [4,5] and face social [6], economic [7] and health problems [8]; many are underserved for healthcare with reduced access to services in the community $[2,9]$. Involvement with criminal behaviour and imprisonment often becomes part of the career of people with OUD [10, 11]. Prisoners may be more likely to engage in a range of risk behaviour related to transmission of $\mathrm{HCV}$ and other blood borne-viruses $[12,13]$. Harm reduction services, such as prison-based needle and syringe programs (PNSPs) and treatment for OUD, are important in reducing $\mathrm{HCV}$ prison incidence [14], and improving overall health outcomes [13]. In Spain, some prisoners have access to PNSP, but coverage remains limited in other European countries [14].

In Europe, prevalence of $\mathrm{HCV}$ infection in prison populations is estimated at $15 \%$ [15]. HCV treatment regimens based on direct-acting antiviral (DAA) medicines have improved efficacy, safety and tolerability profiles compared to historical interferon-based regimens [16]. Twelve DAA medicines have received European regulatory approval since 2011; access to safe and effective treatment has gradually improved for different groups [17]. Despite progress many prisoners still do not receive adequate assessment and opportunity for HCV treatment $[16,18]$. Historically, many prisoners may not have engaged with $\mathrm{HCV}$ services due to a lack of understanding of new treatment options and concerns about the limited chance of successfully accessing treatment [19]. Organisation and infrastructure can make treatment difficult with delays associated with screening, workup and referral for treatment [19]. Access to specialists able to prescribe DAA often limits treatment. Prisoners with sentences less than 6 months may not be considered despite the shorter treatment duration of 2-3 months as a result of limited continuity of care options on release [20].

To date prisoner HCV treatment is limited in many countries in Europe; access to care is highly variable and often limited in prisons in Germany, Italy, France and England. Policy and clinical practice alignment has resulted in HCV treatment of prisoners in certain regions of Spain: national prison service, 2361 [21]; Catalunya, 529 [22]; Valencia 379 [23]. In these countries there are examples of individual prisons or regions where prisoner $\mathrm{HCV}$ treatment has been successful; it is observed that $\mathrm{HCV}$ treatment is not uniformly and easily available to all prisoners. Limited access to $\mathrm{HCV}$ care for prisoners is a missed opportunity as prison represents a point of care for citizens, in some cases, otherwise out of contact with conventional healthcare services.
Policy and effective implementation is a key determinant of the day to day practice in prisoner $\mathrm{HCV}$ care. Analysis and comparison of HCV treatment population sizes in prisons and policy determinants of clinical practice can inform the development of principles for improving prisoner $\mathrm{HCV}$ care in Europe.

\section{Methods}

A structured approach to assess the size of prison populations requiring $\mathrm{HCV}$ treatment in selected EU countries (England, France, Germany, Italy, Spain) was followed. Evidence describing the size and HCV prevalence of prison populations was identified in a search of published literature from 2007 to 2017 in the PubMed database. Search terms included: "hepatitis C", "HCV", "prisons", "prisoners", "prevalence”. Search returned 357 results, 343 were excluded because they did not meet the selection criteria (204 not in relevant countries of study focus, 121 not focused on assessing HCV prevalence, 14 not in prison population, 4 with no abstract available). The 14 sources from search were combined with 14 additional sources from relevant national or international agencies (England 2, France 2, Germany 2, Italy 3 , Spain 5 ). These additional sources were identified by the authors, local experts with extensive relevant experience in prisoner healthcare in each country. Risk of bias was assessed by a previously existing tool for prevalence studies review [24]; results summarized in Appendix. To manage potential bias studies conducted in a small number of prisoners or in limited number of prisons at regional not national level, or limited by lack of randomization in sampling were compared to other evidence and a consensus from authors expert in local prisoner healthcare, agreed. The size of the prison population potentially requiring $\mathrm{HCV}$ care was synthesised based on population size and HCV prevalence evidence.

Mapping of prisoner HCV policy and practice guidance was completed using a common approach for selected countries. Evidence was identified in a standard review of sources. Sources included the publications of relevant government departments (including health and justice) describing evidence of policy or guidance for clinical practice for prisoners or HCV-related healthcare. Responsibility and governance for prisoner $\mathrm{HCV}$ care was identified and recorded from these sources. Policy assessments were based on the review of sources which described: (1) relevant law defining the principle of equivalence of access to healthcare for prisoners, (2) implications of existing national $\mathrm{HCV}$ care plans including guidance specifically in relation to any recommendation on practice in prisons or importance of prisoner care, (3) components of national prison strategy related to 
prisoner $\mathrm{HCV}$ diagnosis and management and also (4) clinical practice guidelines specific to $\mathrm{HCV}$ care in prison. Data from all sources were extracted and assessed by two reviewers familiar with comparative analysis and the therapy area. A consensus on important principles for policy and practice development was developed based on the results of the analysis.

\section{Results}

\section{The size and nature of the prisoner HCV population}

$\mathrm{HCV}$ prevalence among prisoners varies across countries assessed, ranging from 5 to $43 \%$ (Table 1).

Prison populations were described including analysis of sentence length. The size of potential group of prisoners requiring treatment for $\mathrm{HCV}$ was estimated using sentence length to define addressable populations. A sentence length of 1 year, assuming this implies a custody period of 6 months, was considered sufficient time to allow for completion of $\mathrm{HCV}$ treatment in prison. Applying sentence limits to prisoner populations reduces the size of the cohort potentially able to receive $\mathrm{HCV}$ treatment by $50 \%$ for the selected countries. The analysis suggests a total of 35,000 (range: 25-45,000) prisoners potentially requiring $\mathrm{HCV}$ treatment across the 5 countries.

\section{Policy assessment, governance \& funding: prisoner HCV care}

The results of the policy assessment are summarised in Table 2. The Ministry of Health and relevant parts of the national health services are responsible for prison healthcare provision and funding in England, France and Italy at the national level. In Germany, the 16 Ministries of Justice are responsible for funding and provision of general healthcare services in prison. In Spain, in autonomous regions of Catalunya and Country Basque, funding and provision of healthcare in prisons is the responsibility of the regional health service and in the rest of the regions is the Ministry of Interior [25]. In Germany, the level of decision making, funding and provision of healthcare in prisons is devolved to the 16 regions or Länder. In all cases systems for prison healthcare provide reimbursement, in a similar way to the general population, for HCV testing and access to DAA treatment for prisoners able to navigate the journey to treatment. There is consistency of the law that defines the rights of prisoners to equivalent healthcare in all countries assessed (Spain [26], England [27], France [28], Italy [29], Germany [30]).

When comparing results for the selected countries, there are differences in other relevant policy and guidance related to prisoner $\mathrm{HCV}$ care. A national $\mathrm{HCV}$ plan that specifically addressed prisoners as a key risk group is identified for Spain [31], England [32] and France [33]. Prison healthcare policy defining effective $\mathrm{HCV}$ care and published clinical guidelines to facilitate the day-to-day treatment of $\mathrm{HCV}$ in prisons were available in England [34, 35], France [36, 37], Italy [38, 39] and Spain [40, 41]. Policy and guidance likely to lead to progressive, effective clinical practice includes: explicit statement of the rights of prisoners to access to DAA therapies in the context of the development of harm reduction programs with campaigns to screen/educate on HCV risk and actions to ensure medical/ social coverage on release [33].

Relevant examples of effective policy and practice choices include the offering of voluntary HCV screening on entry and after 6 months continuously until release if the result is negative for prisoners and pre-trial detainees [40]. Opt-out HCV screening (rather than opt-in) is effective [42, 43] and use of simple tools such as dried blood spot testing kits is optimal $[35,44,45]$. Best policy and practice also includes clear referral pathways to access treatment delivered by integrated multidisciplinary care teams [35, 45-47]. Set up of services for each prison including a realistic, non-limiting, working relationship with a specialist expert in infectious diseases is advised [46, 48]; achieving continuity of care on release is also an important part of policy and guidance for services [45].

\section{Discussion}

Advances in $\mathrm{HCV}$ treatment and increasing access in the community setting to $\mathrm{HCV}$ care have led to a step change in treatment and outcomes; many prisoners do access $\mathrm{HCV}$ care. Treatment of HCV for prisoners is limited in Germany, increasing but limited in some areas in England, France, and Italy. In Spain there is wider access to care with still further progress needed.

Analysis of prison populations in 5 selected countries in Europe identifies 35,000 (25-45,000) prisoners potentially requiring $\mathrm{HCV}$ treatment. In each country estimated prisoner $\mathrm{HCV}$ populations identified are England and Wales, 9000 (range: 5-13,000), France, 8000 (4-12,000), Spain, 6000 (6-8000), Italy, 6000 (3-6000), Germany, 6000 (6-8000). Evidence describing prisoner $\mathrm{HCV}$ population is often limited and varying data is reported. Number of patients requiring treatment in this work is estimated based on an interpretation of the available studies and experience of experts actively engaged in the treatment system for each respective country. The number is an estimate based on best available sources and it is reasonable to assume from assessing evidence from published sources identified here. The range of population size 
Table 1 A structured review of published literature estimating HCV prevalence in prisoners in 5 European countries

\begin{tabular}{|c|c|c|c|c|c|c|c|c|}
\hline \multirow[t]{2}{*}{ Country } & \multicolumn{2}{|c|}{ HCV prevalence } & \multirow[t]{2}{*}{ Year of study } & \multirow[t]{2}{*}{ Study type } & \multirow{2}{*}{$\begin{array}{l}\text { Sample } \\
\text { Size, N }\end{array}$} & \multirow[t]{2}{*}{ N, Prisons } & \multirow[t]{2}{*}{ Note } & \multirow[t]{2}{*}{ Author, Year (ref) } \\
\hline & $\overline{A b}(\%)$ & $\begin{array}{l}\text { RNA } \\
(\%)\end{array}$ & & & & & & \\
\hline \multirow[t]{7}{*}{ Spain } & 12.8 & 9.9 & 2017 & Cross-sectional & 821 & 1 & $\begin{array}{l}\text { Cantabria - El Dueso } \\
\text { prison }\end{array}$ & Crespo 2017 [49] \\
\hline & $\mathrm{Nr}$ & 9.1 & 2017 & Regional screening & 7051 & 10 & Cataluña & Gencat 2018 [50] \\
\hline & 11.0 & 8.8 & 2016 & Cross-sectional & 1264 & 10 & Cataluña & Marco 2017 [51] \\
\hline & 18.7 & 11.0 & 2016 & $\begin{array}{l}\text { Aggregation of } \\
\text { regional statistics }\end{array}$ & 48,830 & $\mathrm{nr}$ & National data used & $\begin{array}{l}\text { Ministry of Interior } \\
2017 \text { [52] }\end{array}$ \\
\hline & 17.6 & 9.9 & 2016 & Cross-sectional & 204 & 3 & Andalucía & Tellez 2017 [53] \\
\hline & 22.7 & 20.1 & 2008 & Cross-sectional & 378 & 18 & Spain & $\begin{array}{l}\text { Saiz de la Hoya } \\
{[54]}\end{array}$ \\
\hline & 34.2 & $\mathrm{nr}$ & 2008 & Cross-sectional & 730 & 1 & Spain & Murcia 2009 [55] \\
\hline \multirow[t]{6}{*}{ England } & 18.0 & 15.0 & 2014 & $\begin{array}{l}\text { HJIPS opt out } \\
\text { testing programme }\end{array}$ & 8797 & 112 & England & $\begin{array}{l}\text { Public Health } \\
\text { England } 2017 \text { [43] }\end{array}$ \\
\hline & 8.0 & $\mathrm{nr}$ & 2014 & $\begin{array}{l}\text { PHE Sentinel } \\
\text { surveillance }\end{array}$ & 4089 & $\begin{array}{l}\text { Multiple, figure } \\
\text { not mentioned }\end{array}$ & Data not specified & $\begin{array}{l}\text { Public Health } \\
\text { England } 2015 \text { [56] }\end{array}$ \\
\hline & 43.0 & 28.0 & 2013-2014 & Observational & 102 & 1 & Northumberland & Darke 2015 [57] \\
\hline & 19.0 & $\mathrm{nr}$ & 2012 & Cross-sectional & 4904 & 14 & Scotland & Taylor 2012 [58] \\
\hline & 11.0 & $\mathrm{nr}$ & 2010-2011 & Retrospective analysis & 118 & 1 & Oxfordshire & Duncan 2013 [59] \\
\hline & 24.0 & 11.0 & 2005-2008 & $\begin{array}{l}\text { Retrospective analysis } \\
\text { from sentinel survey }\end{array}$ & 9965 & 39 & $\begin{array}{l}\text { England; }\left(N=1490^{*}\right. \\
\text { Ab+ tested for RNA) }\end{array}$ & Kirwan 2011 [60] \\
\hline \multirow[t]{6}{*}{ France } & 15.0 & $\mathrm{nr}$ & 2017 & Survey & 950 & 1 & $\begin{array}{l}\text { Maison d'Arrêt de } \\
\text { Villeneuve-les-Maguelone }\end{array}$ & $\begin{array}{l}\text { Meroueh } 2017 \\
\text { [61] }\end{array}$ \\
\hline & 5.0 & 2.0 & 2012-2013 & Cross-sectional & 342 & 2 & Puy-de-Dome & Jacomet 2016 [62] \\
\hline & $\begin{array}{l}4.8 \text { (Women } \\
\text { 11.8; Men 4.5) }\end{array}$ & 2.5 & 2010 & $\begin{array}{l}\text { Cross-sectional, } \\
\text { questionnaire-based }\end{array}$ & 1876 & 27 & $\begin{array}{l}\text { Prisons stratification by } \\
\text { region and prison type } \\
\text { for selection }\end{array}$ & Semaille 2013 [63] \\
\hline & 13.0 & $\mathrm{nr}$ & 2008 & Survey & $\mathrm{nr}$ & 1 & $\begin{array}{l}\text { Maison d'Arrêt de } \\
\text { Villeneuve-les-Maguelone }\end{array}$ & Meroueh 2008 [64] \\
\hline & 5.0 & $\mathrm{nr}$ & $2004-2010$ & $\begin{array}{l}\text { Cross-sectional } \\
\text { questionnaire } \\
\text { (multiple time points) }\end{array}$ & 5957 & 3 & Southeastern France & Roux 2014 [65] \\
\hline & 5.0 & $\mathrm{nr}$ & $2000-2003$ & Cross-sectional & 597 & 1 & Caen & Verneuil 2009 [66] \\
\hline \multirow[t]{5}{*}{ Italy } & $\mathrm{Nr}$ & 7.4 & 2014 & $\begin{array}{l}\text { Survey, questionnaire- } \\
\text { based }\end{array}$ & 15,751 & 57 & $\begin{array}{l}6 \text { regions: Toscana, Lazio, } \\
\text { Veneto, Liguria, Umbria, } \\
\text { ASL Salerno }\end{array}$ & $\begin{array}{l}\text { Agenzia Regionale } \\
\text { di Sanità } \\
\text { dellaToscana [67] }\end{array}$ \\
\hline & 22.8 & $\mathrm{nr}$ & 2009 & Cross-sectional & 2241 & 9 & $\begin{array}{l}\text { Representative sample } \\
\text { of prisons selected based } \\
\text { on geographical location }\end{array}$ & Sagnelli 2012 [68] \\
\hline & 22.0 & 19.0 & 2006 & Cross-sectional & 695 & 1 & Milan-Opera & Brandolini 2013 [69] \\
\hline & 28.0 & $\mathrm{nr}$ & $2001-2002$ & Cross-sectional & 1091 & 3 & Cassino, Frosinone, Latina & La Torre 2012 [70] \\
\hline & 9.0 & $\mathrm{nr}$ & 2006-2009 & Cross-sectional & na & na & Toscana & Voller 2011 [71] \\
\hline \multirow[t]{4}{*}{ Germany } & 16.0 & $\mathrm{nr}$ & $2006-2007$ & $\begin{array}{l}\text { Cross-sectional } \\
\text { survey analysis }\end{array}$ & 1582 & 6 & $\begin{array}{l}\text { Chemnitz, Hameln, Köln, } \\
\text { Remscheid, Rheinbach, } \\
\text { Zeithain }\end{array}$ & $\begin{array}{l}\text { Eckert \& Weilandt } \\
2008 \text { [72] }\end{array}$ \\
\hline & 16.0 & $\mathrm{nr}$ & $2006-2007$ & $\begin{array}{l}\text { Cross-sectional } \\
\text { (Serology }+ \\
\text { questionnaire) }\end{array}$ & 1519 & 6 & Closed German institutions & Radun 2007 [73] \\
\hline & 14.0 & $\mathrm{nr}$ & 2006 & $\begin{array}{l}\text { Survey, questionnaire- } \\
\text { based }\end{array}$ & 14,187 & 31 & $\begin{array}{l}\text { Based on return of } \\
\text { completed survey from } \\
\text { prison physicians }\end{array}$ & Schulte 2009 [74] \\
\hline & 9.0 & 7.0 & 2002 & Cross-sectional & 1125 & 1 & $\begin{array}{l}\text { German Young Offenders' } \\
\text { Institution }\end{array}$ & Meyer 2007 [75] \\
\hline
\end{tabular}




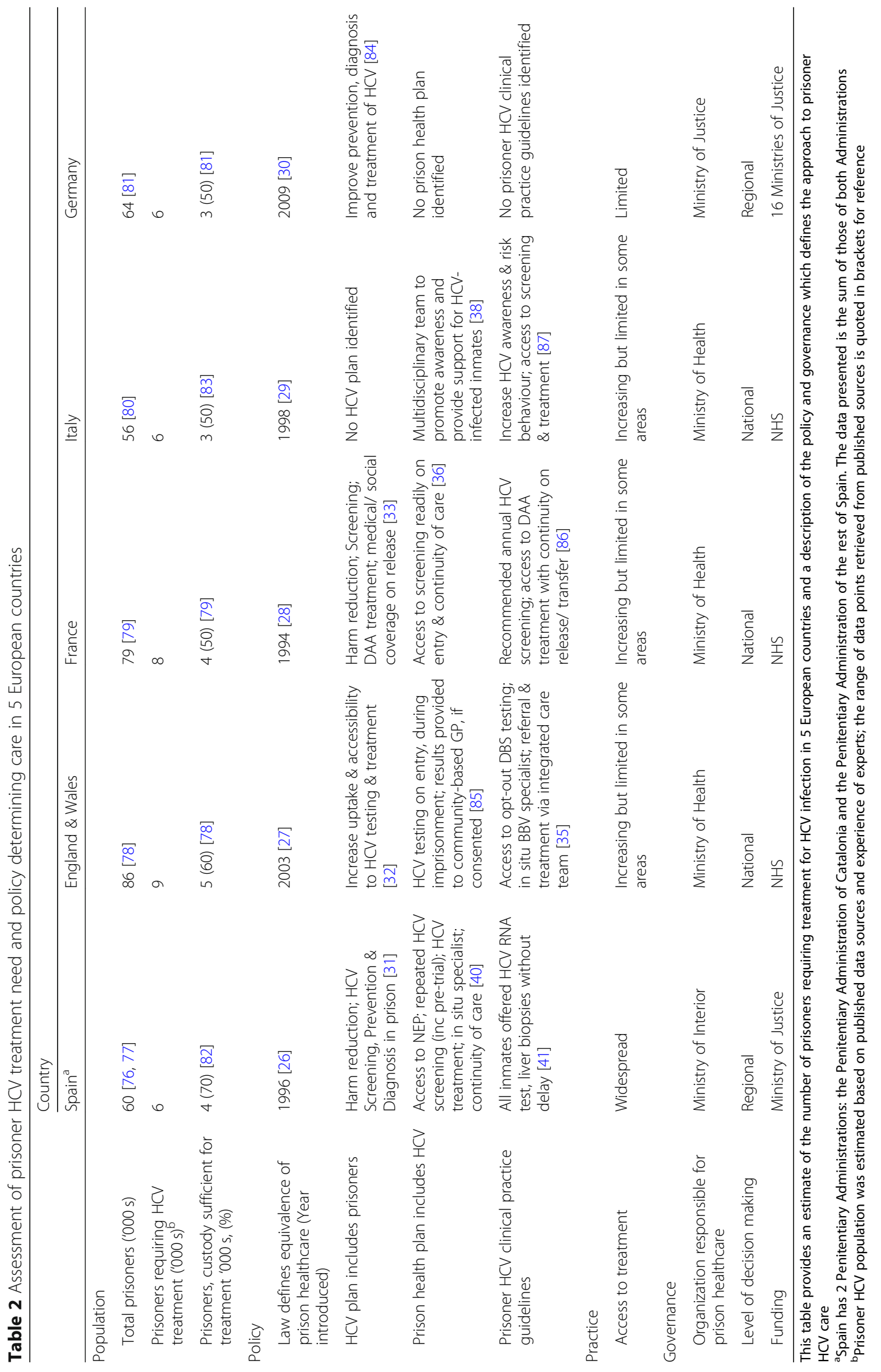


is stated based on available sources; in each case the most likely value for a country was determined by final expert decision. Experts have extensive experience in prison healthcare and the evidence of appropriate population size.

There is important opportunity to improve outcomes for this group for whom access to care can be limited. Policy development and implementation of optimal clinical practice with improved engagement is key for success (e.g. providing education alongside streamlined, efficient screening programs using modern tools to reduce inconvenience and provide essential diagnostic information without excess delay). Sentence or custody length may present a barrier for prisoner assessment and inclusion in $\mathrm{HCV}$ care programs, which can be addressed. Policy and clinical guidelines should ensure that there is equity of selection for prisoners and that sentence length is not used inappropriately to limit treatment. In addition, optimizing treatment process to reduce time and facilitate treatment continuity can make treatment a reality for another 15,000 prisoners with short periods of custody. The right to prescribe modern DAA therapy should be as wide as possible to address access to specialists. Learning from the approach to HIV medicines prescribing is important - non-physician prescribing should be considered where locally possible including models of oversight to enable other $\mathrm{HCP}$ to commence therapy.

Successful treatment of HCV in the prisons is based on clear policy defining equity of access, linked to an integrated treatment approach, which directly addresses potential barriers to success. In locations where policy and treatment approach are aligned and optimal, many prisoners with HCV have been treated and prison acts as an important contact point for $\mathrm{HCV}$ care engagement.

The following principles should be considered as a key part of the approach to providing treatment and improving prisoner $\mathrm{HCV}$ care:

1. Develop and update policy through national and/ or relevant regional (1) HCV care guidelines and (2) prison healthcare guidance to include screening, testing, and treatment of $\mathrm{HCV}$ for prisoners

2. Adopt innovative, local clinical practice guidance including choices to improve engagement and screening, and to make the prisoner $\mathrm{HCV}$ treatment as easy and effective as possible

3. Implement standards and metrics for measuring and reporting activity and outcomes of prisoner $\mathrm{HCV}$ screening and treatment
4. Plan for integrated care models between the community and prison with healthcare record sharing to make treatment continuity the norm during prisoner release

5. Endorse a holistic approach to prisoner health including equitable access to integrated treatment programs for OUD.

Providing a treatment service in prisons consistent with these principles defines a gold standard. In this analysis no prisoner with HCV across any one country achieves full access to HCV care in prisons. Based on observations, it is noted that care is very limited in many areas in Germany, sometimes limited but increasing with areas of success in some areas in Italy, France and England and more commonly available in regions of Spain. All prisoner health services should aim to reach the gold standard of $\mathrm{HCV}$ care.

This work is based on an assessment of current approaches to prisoner $\mathrm{HCV}$ care from 5 countries in Europe. It is likely that these observations are applicable elsewhere: further work to assess the situation in other locations is recommended. Additional input from prison health, OUD and HCV specialists from other countries can add further to the understanding; many of the challenges and successes identified here may apply generally. Consensus on the size of relevant populations is reached based on the available evidence and expert familiarity with the treatment area. It is likely that the consensus represents a strong estimate of population size but this approach is limited - further measurement of prevalence of $\mathrm{HCV}$ in prisons should be undertaken in all settings to confirm the validity or improve this approach.

\section{Conclusion}

Periods of custody in prison are an opportunity for people underserved for healthcare to engage with services and to provide diagnosis, workup and treatment for HCV. Many do not receive $\mathrm{HCV}$ assessments and treatment in prison despite their needs. This qualitative analysis shows there is an opportunity to clarify relevant policy, develop specific guidance and support day-to-day clinical practice in prisons to improve care and use this opportunity. It is important to broaden access, make screening and treatment easier to improve outcomes for prisoner $\mathrm{HCV}$ care in many countries in Europe. This is a key part of the challenge to treat all persons whether in prison or the community with HCV. Further work to update policy and improve access and clinical practice should follow to realise this significant opportunity. 


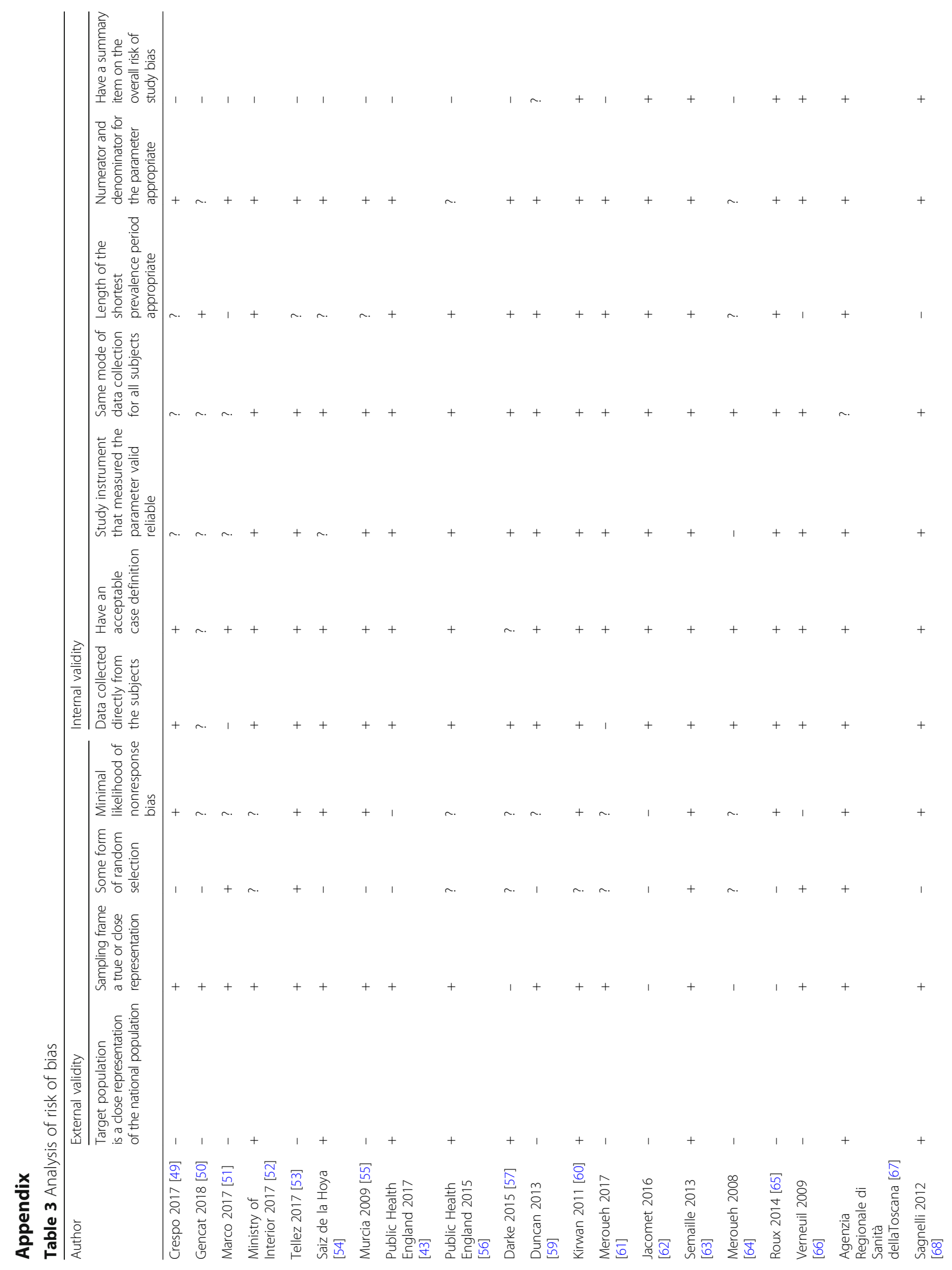


Stöver et al. BMC Public Health

(2019) 19:30

Page 8 of 11

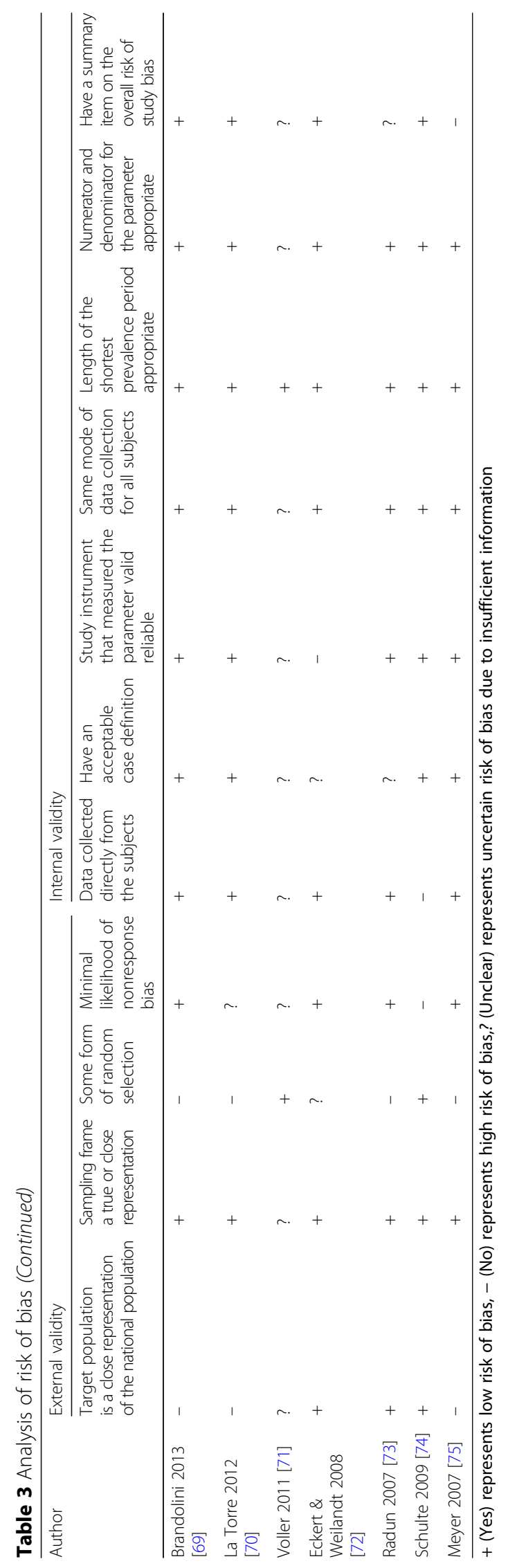




\section{Abbreviations}

DAA: Direct acting antivirals; HCP: Healthcare professional; HCV: Hepatitis C virus; OUD: Opioid use disorder; PNSP: prison-based needle and syringe programs

\section{Acknowledgements}

The authors are grateful for the contribution of Tara Lumley and Dr. Li Li in preparing analysis and editorial works.

\section{Funding}

Gilead Sciences Europe provided funds for the study. Gilead had no influence on the development, research or writing of the manuscript.

\section{Availability of data and materials}

Not applicable.

\section{Authors' contributions}

All authors made equal substantial contributions to conception and design the manuscript, acquisition of data. Authors provided specific review of country data depending on experience (HS, SW, KK, Germany; FM, France; PSdIH, AM, Spain; LS, FN, Italy; NW, FA, RL, UK), all authors participated in an extensive consultation round, provided critical feedback during the manuscript writing process and review to final approval of the manuscript.

\section{Ethics approval and consent to participate}

Not applicable.

\section{Consent for publication}

Not applicable.

\section{Competing interests}

The authors declare that they have no competing interests.

\section{Publisher's Note}

Springer Nature remains neutral with regard to jurisdictional claims in published maps and institutional affiliations.

\section{Author details}

${ }^{1}$ Institute of Addiction Research, Frankfurt University of Applied Sciences, Frankfurt, Germany. ${ }^{2}$ Health Unit, Villeneuve les Maguelone, France. ${ }^{3}$ Penitentiary Program, Catalan Health Institute, Barcelona, Spain. ${ }^{4}$ Justizvollzug, Berlin, Germany. ${ }^{5}$ Health Services of Fontcalent Penitentiary Centre, Alicante, Spain. ${ }^{6}$ Applied strategic, London, UK. ${ }^{7}$ Spectrum Community Health CIC, Wakefield, UK. ${ }^{8}$ University of Modena and Reggio Emilia, University Hospital Policlinico of Modena, Modena, Italy. ${ }^{9}$ Divisiona Medical Director, Central and North West London NHS Foundation Trust, London, UK. ${ }^{10}$ CONCEPT, Addiction Medicine, Munich, Germany. ${ }^{11}$ Addiction Treatment Centre, Biella, Italy.

Received: 10 May 2018 Accepted: 21 December 2018

Published online: 08 January 2019

\section{References}

1. Robaeys G, Grebely J, Mauss S, Bruggmann P, Moussalli J, De Gottardi A, et al. Recommendations for the management of hepatitis $C$ virus infection among people who inject drugs. Clin Infect Dis. 2013;57(Suppl 2):S129-37 [cited 7 Dec 2015].

2. Roncero C, Vega P, Martinez-Raga J, Torrens M. Chronic hepatitis C and individuals with a history of injecting drugs in Spain: population assessment, challenges for successful treatment. Eur J Gastroenterol Hepatol. 2017;29:629-33.

3. Bielen R, Stumo SR, Halford R, Werling K, Reic T, Stöver H, et al. Harm reduction and viral hepatitis $C$ in European prisons: a cross-sectional survey of 25 countries. Harm Reduct J. 2018;15. https://doi.org/10.1186/s12954-0180230-1.

4. Wright N, Reimer J, Somaini L, Roncero C, Maremmani I, Simon N, et al. Are we ready to treat hepatitis $C$ virus in individuals with opioid use disorder: assessment of readiness in European countries on the basis of an expertgenerated model. Eur J Gastroenterol Hepatol. 2017;29:1206-14.

5. Li $\mathrm{V}$, Chen J. The burden of hepatitis $C$ in the injection drug user population the framework of stigma. J Glob Health. 2014. Available from: http://www. ghjournal.org/the-burden-of-hepatitis-c-in-the-injection-drug-userpopulation/. [cited 30 Aug 2017].

6. Daley DC. Family and social aspects of substance use disorders and treatment. J Food Drug Anal. 2013;21. https://doi.org/10.1016/j.jfda.2013.09.038.

7. Bauld L, Hay G, McKell J, Carroll C. Problem drug users' experiences of employment and the benefit system. 2010. ISBN 9781847127297.

8. National Institute on Drug Abuse. Heroin - What are the medical complications of chronic heroin use? Heroin Res Rep Ser. 2014. Available from: https://www.drugabuse.gov/publications/research-reports/heroin/ what-are-medical-complications-chronic-heroin-use. [cited 11 Jan 2018].

9. Lang K, Neil J, Wright J, Dell CA, Berenbaum S, El-Aneed A. Qualitative investigation of barriers to accessing care by people who inject drugs in Saskatoon, Canada: perspectives of service providers. Subst Abuse Treat Prev Policy. 2013;8:35.

10. Larney S, Cama E, Nelson E, Larance B, Degenhardt L. A cross-sectional study of correlates of imprisonment in opioid-dependent men and women in New South Wales, Australia. Drug Alcohol Rev. 2016:35:686-92.

11. Bremer V, Cai W, Gassowski M, Haußig J, Marcus U, Nielsen Stine. Abschlussbericht der Studie "Drogen und chronische Infektionskrankheiten in Deutschland" (DRUCK-Studie). Berlin: Robert Koch-Institut; 2016. Available from: https://doi.org/10.17886/rkipubl-2016-007. [cited 31 December 2018].

12. Moazen B, Moghaddam SS, Silbernagl MA, Lot M, Bosworth RJ, Alammehrjerdi Z, et al. Prevalence of drug injection, sexual activity, tattooing, and piercing among prison inmates. Epidemiol Rev. 2018;40:1-12.

13. Lazarus JV, Safreed-Harmon K, Hetherington KL, Bromberg DJ, Ocampo D, Graf $N$, et al. Health outcomes for clients of needle and syringe programs in prisons. Epidemiol Rev. 2018;40. https://doi.org/10.1093/epirev/mxx019.

14. Bielen $R$, Stumo S, Halford R, Werling $K$, Reic T, Stöver H, et al. Harm reduction and viral hepatitis $C$ in European prisons: a cross-sectional survey of 25 countries. Harm Reduct. J. 2018:15:25.

15. Dolan K, Wirtz AL, Moazen B, Ndeffo-mbah M, Galvani A, Kinner SA, et al. Global burden of HIV, viral hepatitis, and tuberculosis in prisoners and detainees. Lancet. 2016;388:1089-102

16. Zampino R, Coppola N, Sagnelli C, Di CG, Sagnelli E. Hepatitis C virus infection and prisoners: epidemiology, outcome and treatment. World J Hepatol. 2015:7:2323-30.

17. European Medicines Agency. European public assessment reports. Hepatitis C. Chronic; 2018. p. 3-5.

18. Stone J, Martin NK, Hickman M, Hutchinson SJ, Aspinall E, Taylor A, et al. Modelling the impact of incarceration and prison-based hepatitis $C$ virus ( $\mathrm{HCV}$ ) treatment on HCV transmission among people who inject drugs in Scotland. Addiction. 2017:112:1302-14.

19. Mina MM, Herawati L, Butler T, Lloyd A. Hepatitis C in Australian prisons: a national needs assessment. Int J Prison Health. 2016;12:3-16.

20. Apsinall EJ, Mitchell W, Schofiled J, Cairns A, Lamond S, Bramley P, et al. A matched comparison study of hepatitis $C$ treatment outcomes in the prison and community setting, and an analysis of the impact of prison release or transfer during therapy. J Viral Hepat. 2016;23:1009-16.

21. Médicos y Pacientes. La SESP vincula el fin de la hepatitis C a su detección en las cárceles. Madrid; 2018. Available from: http://www. medicosypacientes.com/articulo/la-sesp-vincula-el-fin-de-la-hepatitis-c-sudeteccion-en-las-carceles. [cited 31 December 2018]

22. Grupo Malalties Infecciosas Penitenciaries de ICS. Datos no publicados, Número de pacientes tratados en las prisiones dependientes de la administración catalana (31 Diciembre 2017). 2017.

23. Conselleria de Sanitat Universal i Salut Pública. Antiviral Report for the Hepatitis C in the Community Valencia (01/01/2017 to 08/31/2017). 2017. Available from: http://www.san.gva.es/web_estatica/index_es.html. [cited 4 May 2018].

24. Hoy D, Brooks P, Woolf A, Blyth F, March L, Bain C, et al. Assessing risk of bias in prevalence studies: modification of an existing tool and evidence of interrater agreement. J Clin Epidemiol. 2012;65:934-9.

25. European Monitoring Centre for Drugs and Drug Addiction (EMCDDA). Spain. Country Drug Report - Drug use and responses in prison. 2017. Available from: http://www.emcdda.europa.eu/countries/drug-reports/2017/ spain/drug-use-response-in-prison en. [cited 27 Apr 2018].

26. Ministerio de Justica e Interior. Art. 208. Sec. 1. Decreto 190/1996, de 9 de febrero, por el que se aprueba el Reglamento Penitenciario. TITULO IX. De las prestaciones de la Administración Penitenciaria. 1996. Available from: http://noticias.juridicas.com/base_datos/Penal/rd190-1996.t9.html. [cited 9 Jan 2018]. 
27. HM Prison Service. Prison Service Order ORDER NUMBER 3200 Health Promotion. 2003.

28. Loi n 94-43 du 18 janvier 1994 relative à la santé publique et à la protection sociale. 1994. Available from: https://www.legifrance.gouv.fr/ affichTexte.do?cidTexte=JORFTEXT000000728979. [cited 1 May 2018]

29. Ministero della Sanità. Ritorno della medicina penitenziaria a norma dell'articolo 5 della legge, 30 November 1998 n. 419. 1999.

30. Bundesrecht. Allgemeine Regeln Strafvollzugsgesetz $§ 56$ 2009. http://www. buzer.de/gesetz/1310/a18531.htm.

31. Ministerio de Sanidad SS e I. Plan estratégico para el abordaje de la hepatitis c en el sistema nacional de salud. Madrid. 2015. Available from: http://www.msssi.gob.es/ciudadanos/enfLesiones/enfTransmisibles/docs/ plan_estrategico_hepatitis_C.pdf. [cited 31 December 2018].

32. Public Health England. Hepatitis $C$ in England 2017 report :Working to eliminate hepatitis $C$ as a major public health threat. 2017.

33. Dhumeaux D. Prise en charge thérapeutique et suivi de l'ensemble des personnes infectées par le virus de l'hépatite C; 2016

34. NHS Commissioning DCCPT. Strategic direction for health services in the justice system: 2016-2020 Care not custody, care in custody, care after custody. p. 2016

35. Cox J, Dhuny J, Dodd J. Hepatitis C prevention, diagnosis and treatment in prisons in England; 2016.

36. Ministère des affaires soclales et de la santé M de la J. Stratégie Santé des personnes placées sous main de justice. 2017.

37. Hillon P, Fontaine H, Hanslik B, Hézode C, de Lédinghen V, Pageaux G-P, et al. AFEF guidelines management of hepatitis $C$ virus infection. 2015.

38. Servizio Salute Mentale DP e S nelle C. II percorso clinico-assistenziale per le persone detenute. 2015.

39. Casa di Reclusione di Padova. Linee guida sull'HIV/AIDS e le epatiti in carcere. Milan; 1999. Available from http://www.ristretti.it/areestudio/salute/ norme/guidaaids.htm.

40. Bessa CFB, Lazo GN, Sauret GV, Sauret GV. Improving prison conditions by strengthening the monitoring of HIV, HCV, TB and harm reduction mapping report - Catalonia (Spain) report by OSPDH -Observatory of the Penal System and Human Rights (University of Barcelona). Barcelona. 2015.

41. Saiz de la Hoya-zamácola P, Marco-Mouriño A, Clemente-Ricote G, PortillaSogorb J, Boix-Martínez V, Núñez-Martínez O, et al. Recomendaciones de expertos sobre el diagnóstico y tratamiento de la hepatitis C crónica en el medio penitenciario. Rev Esp Sanid Penit. 2007;9:27-38.

42. Tavoschi L, Vroling H, Madeddu G, Babudieri S, Monarca R, Noordegraafschouten MV, et al. Active case finding for communicable diseases in prison Settings: increasing testing coverage and uptake among the prison population in the European Union / European Economic Area. Epidemiol Rev. 2018;40. https://doi.org/10.1093/epirev/mxy001.

43. Public Health England. BBV bulletin: Special Edition. Quarterly update report of the introduction of opt-out BBV testing in prisons from PHE, NHS England and HMPPS. 2017. Available from: https://assets.publishing.service. gov.uk/government/uploads/system/uploads/attachment_data/file/666850/ BBV_bulletin_Dec_2017.pdf.

44. Morey S, Hamood A, Valappip M, Jones D, Thompson C, Dhuny J, et al. A universal offer of blood borne virus testing substantially increases diagnosis and treatment of HCV in prisons. J Hepatol. 2018;68(1):s307-S308.

45. Ekeke N, Francis-Graham S, King T, Demma S, Macdonals D, Rosenberg W. Poster presented at EASL. Improving detection and management of HCV infection in prisons. EASL 2018 - Eur Assoc Study Liver; 2018. p. 2018.

46. Remy A, Guillaume B, Arnaud H, Hakim B, Stéphane M. COMPASS project. Inside and outside link for inmates and PWID with hepatitis B or C in France, first results. Perpignan. 2016. Available from: https://www.eiseverywhere.com/ file_uploads/7cfc55fea5c77cee07bfd9172010b3dd_Andr-JeanRemy-61.pdf.

47. Bouteille-Gaillet M. Prisons et comorbidités - Prise en charge de l'hépatite $C$ en détention. 2016. Available from: http://vih.org/20160607/prise-en-chargeIhepatite-c-en-detention/138211. [cited 9 May 2018].

48. Llerena S, Mateo M, Cobo C, Blasco A, Cabezas J, Lázaro P, Crespo J. Efficiency of a Telemedicine Program in the Management of Hepatitis C in Inmates. J Hepatol. 2018; 68(S1): 53A. Available from: https://aasldpubs. onlinelibrary.wiley.com/doi/full/10.1002/hep.30256. [cited 31 December 2018].

49. Crespo J, Llerena S, Cobo C, Cabezas J. ¿ Es posible la eliminación del virus de la hepatitis C en el entorno penitenciario? Rev Esp Sanid Penit. 2017;19:70-3.

50. Generalitat de Catalunya. Descriptors estadistics serveis penitenciaris. 2017. Available from: http://www.gencat.cat/justicia/estadistiques_serveis_ penitenciaris/12_pob.html. [cited 7 Mar 2018].
51. Marco A, Valls I, Guerrero RA, Turu E. La eliminación de la hepatitis C en prisión es posible. Predicción de la eliminación en las prisiones de Cataluña (España); 2017.

52. Informe General 2016. Ministerio del Interior Secretaría General de Instituciones Penitenciarias. 2016. Available from http://www.interior.gob.es/ documents/642317/1202140/Informe_General_IIPP_2016_12615039X.pdf/ 3d3b743f-4527-453a-a185-2b3976f724bf. [cited 31 Dec 2018].

53. Tellez F. El especialista hospitalario. Estrategias para mejorar la coordinacion con otras unidades: Farmacia, prisiones, y centros de tratamientos de adicciones. Data presented at GEHEP-SEIMC. 2017. Available from: http:// www.gehep2017.org/images/site/ponencias/03_Sabado_30/Sabado_10.30_ 11.30h/Conf_Especial_P_3_F_Tellez.pdf.

54. De La Hoya PS, Marco A, García-Guerrero J, Rivera A. Hepatitis c and b prevalence in Spanish prisons. Eur J Clin Microbiol Infect Dis. 2011;30:857-62.

55. Murcia J, Portilla J, Bedia M, Palazon JM, Sanchez-Paya J, de la Hoya Saiz P, et al. Chronic hepatitis $C$ virus infection and associated liver disease among the inmates of a Spanish prison. Enferm Infecc Microbiol Clin. 2009;27:206-12.

56. Public Health England. Health and Justice Report 2014. London. p. 2015. Available from: https://www.gov.uk/government/uploads/system/uploads/ attachment_data/file/562775/Health_and_justice_report_2014.PDF. [cited 31 December 2018].

57. Darke J, Cresswell T, McPherson S, Hamoodi A. Hepatitis C in a prison in the North East of England: What is the economic impact of the universal offer of testing and emergent medications? J Public Heal (United Kingdom). 2016;38:e554-62.

58. Taylor A, Munro A, Allen E, Dunleavy K, Cameron S, Miller L. Hepatitis C prevalence and incidence among Scottish prisoners and staff views of its management. Final report. 2012.

59. Duncan S, Sherrard J. Experience of Screening For Hepatitis $C$ in an Oxfordshire Prison FREE; 2013. p. P3.442.

60. Kirwan P, Evans B, Brant L. Hepatitis C and B testing in English prisons is low but increasing. J Public Health (Bangkok). 2011. https://doi.org/10.1093/ pubmed/fdr011.

61. Meroueh F. HCV elimination in prison is feasible: a French experience. Presented at WHO Regional Office for Europe international meeting on prisons and health in joint collaboration with Public Health England (PHE) and European Monitoring Centre for Drugs and Drug A. 2017. Available from: https://justica.gov.pt/Portals/0/Programa\%20do\%20Encontro\%20 Internacional\%20sobre\%20a\%20Saúde\%20nas\%20Prisões\%20$\% 2011 \% 20 d e z \% 2017 . p d f ? v e r=2017-12-13-164252-827$. [cited 10 May 2018]

62. Jacomet C, Guyot-lénat A, Bonny C, Henquell C, Rude M, Dydymski S, et al. Addressing the challenges of chronic viral infections and addiction in prisons : the PRODEPIST study. Eur J Pub Health. 2016;26:122-8.

63. Semaille C, Le SY, Chiron E, Chemlal K, Valantin MA, Serre P, et al. Prevalence of human immunodeficiency virus and hepatitis $C$ virus among French prison inmates in 2010: a challenge for public health policy separator commenting unavailable. Eurosurveillance. 2013;18. https://doi. org/10.2807/1560-7917.ES2013.18.28.20524.

64. Meroueh F. Traiter le VHC en prison: une initiative salutaire. Assoc pour la Commun sur les Prison l'incarcération en Eur. 2008. Available from: http:// prison.eu.org/spip.php?article10630. [cited 9 May 2018].

65. Roux P, Sagaon-Teyssier L, Lions C, Fugon L, Verger P, Carrieri MP. HCV seropositivity in inmates and in the general population: an averaging approach to establish priority prevention interventions. BMJ Open. 2014; 4:1-10.

66. Verneuil L, Vidal JS, Ze Bekolo R, Vabret A, Petitjean J, Leclercq R, et al. Prevalence and risk factors of the whole spectrum of sexually transmitted diseases in male incoming prisoners in France. Eur J Clin Microbiol Infect Dis. 2009. https://doi.org/10.1007/s10096-008-0642-z.

67. Agenzia Regionale di Sanità dellaToscana. La salute dei detenuti in Italia: i risultati di uno studio multicentrico. Toscana; 2015. Available from: http:// www.sanita24.ilsole24ore.com/pdf2010/Sanita2/_Oggetti_Correlati/ Documenti/Regioni-e-Aziende/Carcere.pdf. [cited 31 December 2018].

68. Sagnelli E, Starnini G, Sagnelli C, Monarca R, Zumbo G, Pontali E, et al. Blood born viral infections, sexually transmitted diseases and latent tuberculosis in Italian prisons: a preliminary report of a large multicenter study. Eur Rev Med Pharmacol Sci. 2012;16:2142.

69. Brandolini M, Novati S, De Silvestri A, Tinelli C, Patruno SFA, Ranieri R, et al. Prevalence and epidemiological correlates and treatment outcome of HCV infection in an Italian prison setting. BMC Public Health. 2013;13:981 [cited 9 Feb 2016]. 
70. La Torre G, Vezzo D, Arcese R. Occurrence and correlates of HIV and hepatitis B/C virus infections among prisoners of Southern Lazio, Italy; 2012

71. Voller F, Silvestri C, Orsini C, Aversa L, Da MF, Cipriani F. The health conditions of prison inmates in Tuscany. Epidemiol Prev. 2011;35:297-306.

72. Eckert J, Weilandt C. Infektionskrankheiten unter Gefangenen in Deutschland: Kenntnisse, Einstellungen und Risikoverhalten, Teilergebnisse des Projekts: "Infectious Diseases in German Prisons Epidemiological and Sociological Surveys among Inmates and Staff". Bonn; 2008. Available from: http://www.ahnrw.de/newsletter/upload/01_ NL_ahnrw/2008/2008_10_01_NL20/Endbericht_Gefangene_060808_ kompl.pdf. [cited 31 December 2018].

73. Radun D, Weilandt C, Eckert J, Schüttler C, Weid F, Kücherer C. Crosssectional study on seroprevalence regarding hep $b$, hep $c$ and hiv, risk behaviour, knowledge and attitudes about bloodbone infections among adult prisoners in Germany - Preliminary Results. Eur Sci Conf Appl Infect Dis Epidemiol - ESCAIDE. 2007; Available from: http://www.daignet.de/sitecontent/die-daig/fachorgan/pdfs/eur-j-med-res12-suppl-I-143.pdf. [cited 31 December 2018].

74. Schulte B, Stover H, Thane K, Schreiter C, Gansefort D, Reimer J. Substitution treatment and HCV/HIV-infection in a sample of 31 German prisons for sentenced inmates. Int J Prison Health. 2009:5:39-44.

75. Meyer MF, Wedemeyer H, Monazahian M, Dressman J, Manns MP, Lehmann M. Prevalence of hepatitis $C$ in a German prison for young men in relation to country of birth. Epidemiol Infect. 2007. https://doi.org/10.1017/ S0950268806006820.

76. Departament de Justícia. Descriptors estadistics de Serveis Penitenciaris I de Rehabilitació. 2018. Available from: http://www.gencat.cat/justicia/ estadistiques_serveis_penitenciaris/1_pob.html. [cited 23 Apr 2018].

77. Anuario Estadístico del Ministerio del Interior 2017. Ministerio del Interior. 2017. Available from http://www.interior.gob.es/documents/642317/ 1204854/Anuario_estadistico_2017_con_accesibilidad_EN_LINEA.pdf/ 09bb0218-7320-404c-9dd5-58f4edec914f. [cited 31 Dec 2018].

78. Offender Management Statistics. England \& Wales prison population 2017 London; 2017. Available from: https://www.gov.uk/government/statistics/ offender-management-statistics-quarterly-april-to-june-2017. [cited 31 December 2018].

79. Ministère de la Justice. Les chiffres-clés de la Justice 2017. Paris; 2017. Available from: http://www.justice.gouv.fr/art_pix/stat Chiffres\%20Cl\%E9s\%202017.pdf. [cited 31 December 2018].

80. Ministero Della Giustizia. Detenuti presenti - aggiornamento al 28 febbraio 2017 28. Statistiche. 2017. Available from: https://www.giustizia.it/giustizia/it/ mg_1_14_1.page?facetNode_1=1_5_36\&contentld= SST1315635\&previsiousPage=mg_1_14. [cited 11 Jan 2018].

81. Statistisches Bundesamt. Rechtspflege: Bestand der Gefangenen und Verwahrten in den deutschen Justizvollzugsanstalten nach ihrer Unterbringung auf Haftplätzen des geschlossenen und offenen Vollzugs jeweils zu den Stich- tagen 31, März, 31. August und 30. November eines Jahres. Wiesbaden; 2017. Available from: https://www.destatis.de/DE/ ZahlenFakten/GesellschaftStaat/Bevoelkerung/Ehescheidungen/Tabellen/ EhescheidungenKinder.html. [cited 31 December 2018].

82. Secreteria General de Instituciones Penitenciarias. Informe General 2016. Madrid; 2016.

83. Istituto Nazionale di Statistica. I Detenuti Nelle Carceri Italiane. Rome; 2015 Available from: http://www.istat.it. [cited 31 December 2018].

84. Bundesministerium für Gesundheit. Strategie zur Eindämmung von HIV, Hepatitis B und C und anderen sexuell übertragbaren Infektionen, BIS 2023 - Bedarfsorientiert, Integriert, Sektorübergreifend. Berlin; 2016. Available from: https://www.bundesgesundheitsministerium.de/fileadmin/Dateien/5_ Publikationen/Praevention/Broschueren/Strategie_BIS_2030_HIV_HEP_STI. pdf. [cited 31 December 2018].

85. National institute for Health and Care Excellence. Physical health of people in prison. 2016. Available from: https://www.nice.org.uk/ guidance/ng57.

86. AFEF guidelines. Recommandations AFEF sur la prise en charge des hépatites virales C. Available from https://afef.asso.fr/wp-content/uploads/ 2018/06/Recoavril2016.pdf.

87. Sarzotti C, Unito DS. Interventi di riduzione del danno efficaci secondo le linee guida internazionali 2013. Torino; 2013.

Ready to submit your research? Choose BMC and benefit from:

- fast, convenient online submission

- thorough peer review by experienced researchers in your field

- rapid publication on acceptance

- support for research data, including large and complex data types

- gold Open Access which fosters wider collaboration and increased citations

- maximum visibility for your research: over $100 \mathrm{M}$ website views per year

At $\mathrm{BMC}$, research is always in progress.

Learn more biomedcentral.com/submissions 